\title{
Makna Mitos Pada Karakter Hewan Dalam Film Mononoke Hime
}

\author{
Rizka Anindita $^{\text {() }}$, Ely Triasih Rahayu ${ }^{2)}$, Diana Puspitasari ${ }^{3)}$ \\ PS Sastra Jepang FIB, Universitas Jenderal Soedirman \\ Purwokerto, Jawa Tengah \\ Email : ${ }^{1}$ [rizkaanindita6@gmail.com], ${ }^{2}$ [ely.rahayu@ unsoed.ac.id], \\ 3 [dianapuspitasari@unsoed.ac.id]
}

\begin{abstract}
Abstrak
Tujuan dari penelitian ini adalah untuk mendeskripsikan makna yang terkandung dalam karakter hewan di film Mononoke Hime lalu di kaitkan dengan cerita rakyat Jepang. Jenis penelitian ini adalah deskriptif kualitatif. Teknik pengumpulan data yang digunakan adalah teknik simak catat. Peneliti menyimak film Mononoke Hime dan mencatat dialog yang berkaitan dengan tema penelitian. Teknik analisis data dilakukan dengan menganalisis dialog dalam film Mononoke Hime terkait pemaknaan hewan berdasarkan konsep semiotika Ronald Barthes. Hasil penelitian ini menunjukkan adanya 4 karakter hewan yang memiliki makna mitos berdasarkan analisis dari film Mononoke Hime serta buku referensi Youkai. Hasil penelitian ini menunjukkan 4 hewan yang ditemukan pada sumber data yaitu rusa, serigala, babi hutan dan kera. Masing-masing hewan memiliki karakter sebagai berikut ; dewa rusa memiliki makna pengatur kehidupan makhluk hidup didalam hutan, dewa serigala dan dewa babi hutan memiliki makna pelindung hutan, serta dewa kera bermakna kesuburan dengan merawat hutan dewa rusa.
\end{abstract}

Kata Kunci : film, mitos, makna, youkai, kami

\begin{abstract}
The objective of this study was to describe the meaning contained in the animal characters in the Mononoke Hime movie and then correlated it to Japanese folklore. Type of this study was descriptive qualitative. The data collection technique used was the note taking technique. The researcher watched the Mononoke Hime movie and recorded dialogues related to the study theme. The data analysis technique was conducted by analyzing the dialogues in the Mononoke Hime movie related to the meaning of animals based on Ronald Barthes' semiotic concept. The results of this study showed that there were 4 animal characters that contained mythical meanings based on the analysis of the Mononoke Hime movie and the Youkai reference book. The results of this study showed 4 animals found in the data source, namely deer, wolf, boar and monkey. Each animal had the following characters; The God of deer had the meaning of regulator of living things's lives in the forest, the god of wolf and the god of boar had the meaning of protecting the forest, and the god of monkey had the meaning of fertility by caring for the god of deer's forest.
\end{abstract}

Keywords: movie, myth, meaning, youkai, kami

\section{Pendahuluan}

Mitos merupakan sistem komunikasi dimana ia adalah sebuah pesan apabila kita dapat menelaah makna mitos itu secara mendalam. Mitos tidak dapat dijelaskan secara objek maupun materinya, sebab materi apapun dapat didukung oleh makna yakni sebagai penanda sebuah rambu-rambu. Mitos juga tidak ditentukan oleh objek pesannya saja, akan tetapi bagaimana cara dia mengutarakan pesan itu sendiri. Selain itu biasanya mitos dilandasi dengan kepercayaan masyarakat sekitar yang meyakini jika mitos ini benar 
adanya. Mulai dari mulut ke mulut sampai akhirnya dipercaya oleh banyak orang hingga pada zaman modern abad 20 ini.

Selain itu, media biasanya merefleksikan dan mengangkat mitos-mitos ke dalam beraneka ragam seperti artikel, film, animasi, pertunjukan bahkan pameran. Animasi adalah sebuah karya seni berbentuk gambar bergerak yang terdiri dari sekumpulan objek (gambar) yang disusun secara beraturan mengikuti alur pergerakan yang telah ditentukan pada setiap pertambahan hitungan waktu yang terjadi. Kita dapat membuat berbagai macam gambar seperti gambar makhluk hidup, benda mati, maupun tulisan. Seperti yang kita ketahui animasi di Jepang yaitu Anime cukup populer dan digemari banyak orang khususnya kaum milenial. Kata anime itu sendiri diambil dari serapan bahasa Inggris yaitu Animation pada tahun 1970-an. Selain dari penggambaran karakter tokoh-tokohnya, kita juga dapat melihat dari segi alur ceritanya unik, grafik yang menarik, dan latar tempat yang dapat memanjakan mata.

Film ini bercerita tentang seorang anak remaja bernama Ashitaka yang terkena kutukan mematikan dari roh seekor babi bernama Nago. Lalu demi menyembuhkan dan menghilangkan kutukan tersebut dia harus berkelana ke barat untuk menemui dewa hutan yaitu Shishigami atau dewa rusa. Di perjalanan, Ashitaka terbentur dengan konflik antara Eboshi dan orang-orang dari kota besi dengan San, yaitu seorang gadis yang dibesarkan oleh roh serigala dan berusaha mencegah manusia untuk merusak alam dan menghancurkan tempat tinggalnya beserta makhluk-makhluk di dalamnya.

Film ini berkaitan dengan makna mitos yang diwujudkan pada karakter hewan yang digambarkan oleh Miyazaki Hayao seperti dewa hutannya seekor rusa, penjaga hutannya roh seekor serigala dan babi, roh monyet yang membawa kesuburan hutan, dan kodama yaitu roh penjaga pohon. Yang menarik adalah karakter yang memiliki makna secara mitos dalam kajian mitos Jepang ini, sangat berkaitan dengan perwatakan dari manusia maupun dewa. Sehingga karakter hewan akan dianalisis dengan makna mitos.

Penulis memilih film ini sebagai bahan penelitian karena film Mononoke Hime ini mendapatkan Penghargaan Akademi Jepang untuk film terbaik dan Mainichi Eiga Concours Award for the best film. Seperti yang di ketahui jika masyarakat Jepang mempercayai adanya Youkai atau roh. Youkai adalah makhluk dalam cerita rakyat Jepang yang terdiri dari setan Oni sampai dengan Kitsune atau wanita salju Yuki-Onna dan beberapa ada yang berwujud hewan dan manusia ( seperti Kappa dan Tengu ). Selain tokoh-tokohnya, film ini juga menyinggung isu kepedulian terhadap lingkungan dan ikatan hubungan di dalam ceritanya yaitu seperti masing-masing hewan ini memiliki 
peran dan pekerjaan tersendiri demi menjaga hutannya. Sehingga penulis bisa membandingkan dan mengaitkan dengan cerita masyarakat yang dipercaya dan dianut masyarakat Jepang itu sendiri. Maka permasalahan yang dapat dijadikan sebagai pertanyaan penelitian adalah sebagai berikut :

1. Bagaimanakah karakter hewan digambarkan dalam film Mononoke Hime?

2. Bagaimanakah makna mitos dari karakter hewan dalam film Mononoke Hime?

\section{Metode dan Teori}

\subsection{Metode Penelitian}

Metode penelitian adalah langkah yang dimiliki dan dilakukan oleh para peneliti guna untuk mengumpulkan infomasi atau data serta melakukan investigasi pada data yang telah didapatkan. Metode penelitian memberikan gambaran rancangan penelitian yang meliputi antara lain prosedur dan langkah-langkah yang harus ditempuh, waktu penelitian, dan sumber data yang selanjutnya data-data tersebut diolah dan dianalisis.

Penelitian ini menggunakan metode penelitian deskriptif kualitatif. Menurut Sugiyono (2005) Penelitian kualitatif tersebut merupakan penelitian yang digunakan untuk meneliti pada kondisi objek alamiah dimana peneliti merupakan instrumen kunci. Peneliti kualitatif percaya bahwa kebenaran ialah dinamis dan dapat ditemukan hanya melalui penelaahan terhadap orang-orang melalui interkasinya dengan situasi sosial mereka (Danim, 2002). Teknik yang dilakukan peneliti untuk memperoleh sumber data penelitian adalah dengan menggunakan teknik simak catat. Penulis harus menyimak dan memahami sumber data lalu mencatat semua hal yang bersangkutan dengan penelitian secara teliti, rapi dan benar. Penelitian ini mendeskripsikan isu yang terkandung dari film Mononoke Hime.

\subsection{Teori}

Ketika sebuah sejarah telah berakar kuat dan dianggap sebagai suatu yang ada secara alamiah dan proses sosial yang diperlakukan sebagai hal yang lumrah atau wajar ini oleh Roland Barthes disebut sebagai mitos. Bahkan, Roland Barthes menyatakan bahwa mitos adalah permintaan kedua dalam kerangka semiologis dimana tanda-tanda dalam permintaan utama kerangka menjadi penanda dalam kerangka berikutnya. Pada akhirnya, sebuah tanda dalam kerangka fonetik berubah menjadi tanda dalam kerangka legenda. Hubungan antara penanda dan yang tersirat disebut "penandaan" (Berger 2010:66). 
Barthes menyebut mitos adalah suatu sistem komunikasi atau suatu pesan. Barthes mengartikan mitos tidak sebagai objek pesannya tetapi cara menyatakan pesan. Bukanlah isi dari mitos yang menjadi perhatian Barthes, namun bagaimana masyarakat melupakan proses sejarah dibalik terbentuknya mitos tersebut dan menganggapnya sebagai hal yang alami. Penanda mitos hadir dalam keadaan rancu. Maksud dari keadaan rancu ini adalah pada saat yang bersamaan, ia adalah makna sekaligus bentuk, di satu sisi penuh namun di sisi lain justru kosong. Namun yang mendasar dari semua ini adalah bahwa bentuk di dalam tidaklah menyembunyikan makna, ia memiskinkan makna, ia menempatkannya pada jarak tertentu dan membuat makna tersebut menjadi sesuatu yang bisa digunakan.

\section{Hasil dan Pembahasan}

Kami adalah bentuk legenda jepang yang masih disembah dan diyakini ada dikehidupan masyarakat sekitar. Maka dari itu Hayao Miyazaki menggambarkan agama Shinto untuk berkomunikasi dengan penontonnya yaitu dengan menggunakan penyampaian pentingnya melestarikan alam, keseimbangan hubungan antara manusia dan alam, serta dampak dari perbuatan yang manusia lakukan terhadap alam di dalam filmnya. Selain itu, Hayao Miyazaki juga mengkaitkan jelmaan hewan tersebut dengan Youkai. Berikut adalah penjelasan mengenai hewan yang diangkat dicerita ini :

\subsection{Rusa (鹿, 'Shika')}

Dewa rusa, Shishigami ataupun Great Forest Spirit ini diceritakan memiliki kekuatan tertinggi di film ini karena dapat memberikan kehidupan dan kematian bahkan dapat menyembuhkan penyakit dan juga menghilangkan kutukan. Ia adalah penguasa hutan tempat tinggal semua makhluk hidup. Ia digambarkan memiliki tanduk berwarna hijau yang berbentuk seperti cabang pohon, berwajah seperti manusia, dan memiliki badan layaknya rusa dengan masing-masing kaki memiliki 3 jari saja. Shishigami ini memiliki kuasa penuh atas seluruh unsur alam 
yang hidup di hutannya. Ia dapat memberikan dan mengambil kehidupan seluruh makhluk hidup. Hayao Miyazaki menjelaskan mengapa ia menggunakan wujud rusa sebagai Kami karena rusa dianggap penjelmaan Kami dalam agama Shinto. Dibalik itu, ternyata kisah yang dipercayai oleh masyarakat jepang jika rusa memang dianggap hewan suci dan sakral pada zaman dahulu karena dalam agama Shinto, rusa diyakini sebagai utusan para dewa. Bahkan penduduk setempat tidak boleh dan dilarang ada yang menyakiti hewan suci ini. Bahkan dewa rusa ini juga disebutkan dalam beberapa naskah dan dipercayai keberadaannya.

Berikut dialog antara Ashitaka dan Jikubou pada saat berteduh dan membicarakan tentang kebenaran dari Shishigami :

\section{Dialog 11}

Jikobou : “これより更に西へ西へ進むと、山の奥のまた山奥に、人を寄せ つけぬ 深い森がある。シシ神の森だ”

kore yori sara ni nishi e nishi e susumu to, yama no oku no mata yamaoku ni, hito o yosetsukenu fukai mori ga aru. shishigami no mori da

'kalau pergi jauh ke arah barat, di dalam gunung, ada sebuah hutan lebat yang tidak bisa dijangkau manusia. Itu hutan dewa rusa'

Ashitaka : “シシ神の森?”

shishigami no mori?

'hutan dewa rusa?'

Jikobou：“そこでは獣はみな大きく、太古のままに生きていると聞いた” Soko dewa kemono wa mina daikiku, taiko no mama ni ikiteiru to kiita 'aku pernah dengar, hewan-hewan disana sangat besar pada berabadabad lalu'

Analisis data berdasarkan dialog diatas menunjukkan kebenaran tentang adanya makhluk mitologi bernama Shishigami ini dinyatakan benar oleh Jikobou yaitu makhluk mitos ini berada di dalam sebuah hutan gunung disebelah barat yang disebut hutan dewa rusa. 
Di film Princess Mononoke ini pada malam hari Shishigami dapat berubah wujud menjadi Daidarabotchi yang tampak seperti gambar 1.3 di bawah. Daidarabotchi disebut juga dengan pejalan malam atau Nightwalker. Berbadan raksasa, berwarna biru juga memiliki persamaan dengan Shishigami. Menurut kepercayaan masyarakat jepang, Daidarabotchi merupakan salah satu youkai yang ada dalam mitologi Jepang yang dipercaya sebagai pelindung bumi. Ia juga dapat memimdahkan gunung dan membuat danau. Dengan badan raksasanya, membuat ia dengan mudah berjalan - jalan bertugas

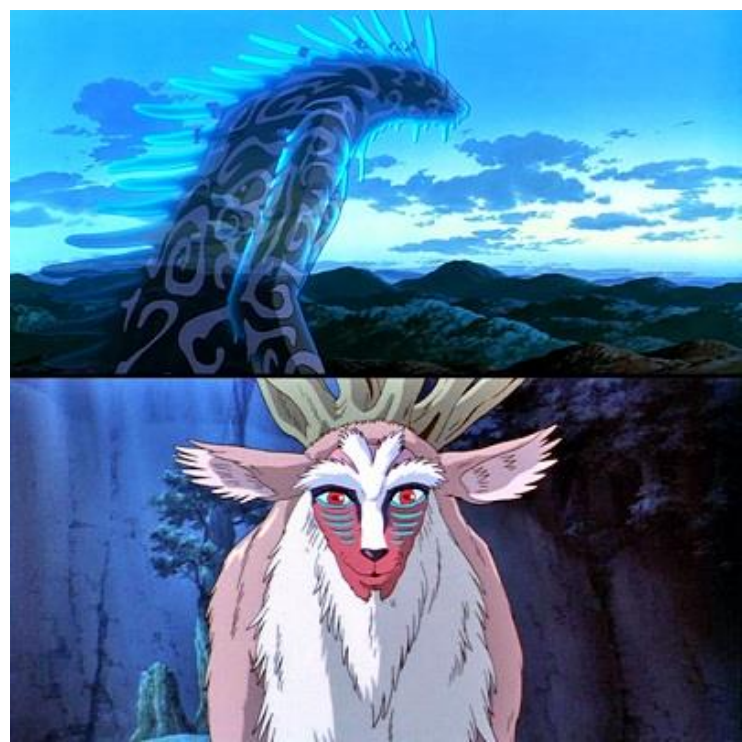

Gambar 1.3 Daidarabotchi dan Shishigami

untuk menjaga dan mengawasi alam pada malam hari. Warna biru Daidarabotchi menandakan perlindungan dan harmonisasi alam.

\subsection{Serigala (狼, 'Okami')}

Di film Princess Mononoke ini, dewa serigala atau Inugami juga merupakan Kami yang dianggap memiliki kekuatan mistis oleh masyarakat jepang. Inugami yang diceritakan di film bernama Moro. Moro adalah pemimpin dari kelompok Inugami dan serigala yang berukuran sangat besar. Ia memiliki anak serigala lainnya dan seorang anak manusia bernama San, yang ia besarkan dengan kasih sayang layaknya anaknya sendiri. Dimana diceritakan ia juga dapat berkomunikasi dengan manusia dan memiliki tugas untuk melindungi hutan dan Shishigami. Selain itu, Moro juga memiliki umur abadi yang membuatnya dapat hidup hingga ratusan tahun lamanya. 
Seperti yang digambarkan dari film ini, Inugami ini merupakan roh yang setia pada pemiliknya seperti Moro yang sangat setia dengan Shishigami dan siap melindungi hutan beserta makhluk didalamnya seperti seorang penjaga hutan. Namun, hutan dan Shishigami diperlakukan semena-mena oleh manusia sehingga Inugami bekerja sama dengan Inoshishigami untuk menyerang manusia.

Terdapat percakapan antara Gonza dan Eboshi yang sedang berperang melawan Inugami di dalam tebing gunung. Lalu adegan Moro terkena peluru dari pasukannya dan Eboshi memberitahu jika Moro tidak akan semudah itu mati hanya dengan senapan seperti itu. Isi percakapan ini adalah sebagai berikut :

Dialog 5

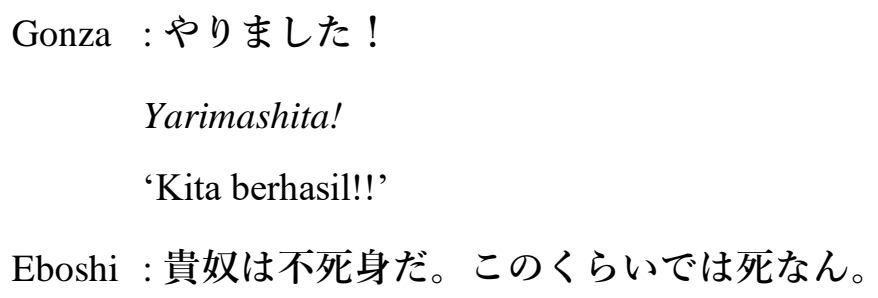

'Dia abadi. Dia tidak akan mati hanya dengan sesuatu seperti itu' Analisis dari beberapa percakapan diatas adalah Moro tidak akan mati hanya karena senapan peluru biasa karena Moro adalah makhluk abadi yang kuat.

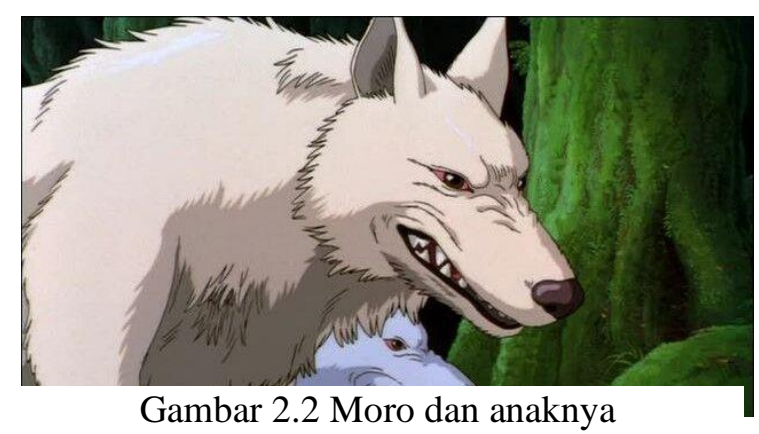

\subsection{Babi (イノシシ, 'Inoshishi’)}

Di film Princess Mononoke juga ditampilkan dewa babi atau Inoshishigami yang berbentuk seperti babi hutan berukuran besar berwarna coklat tua dan abu-abu.

Diceritakan Inoshishigami datang jauh dari utara untuk membalas kematian temannya Nago karena ulah manusia yang telah merusak hutan. Okkoto nushi menjadi salah satu korban dari keserakahan manusia dan berubah menjadi dewa iblis yang terkutuk atau di sebut juga dengan Tatari gami (タタリ神). 

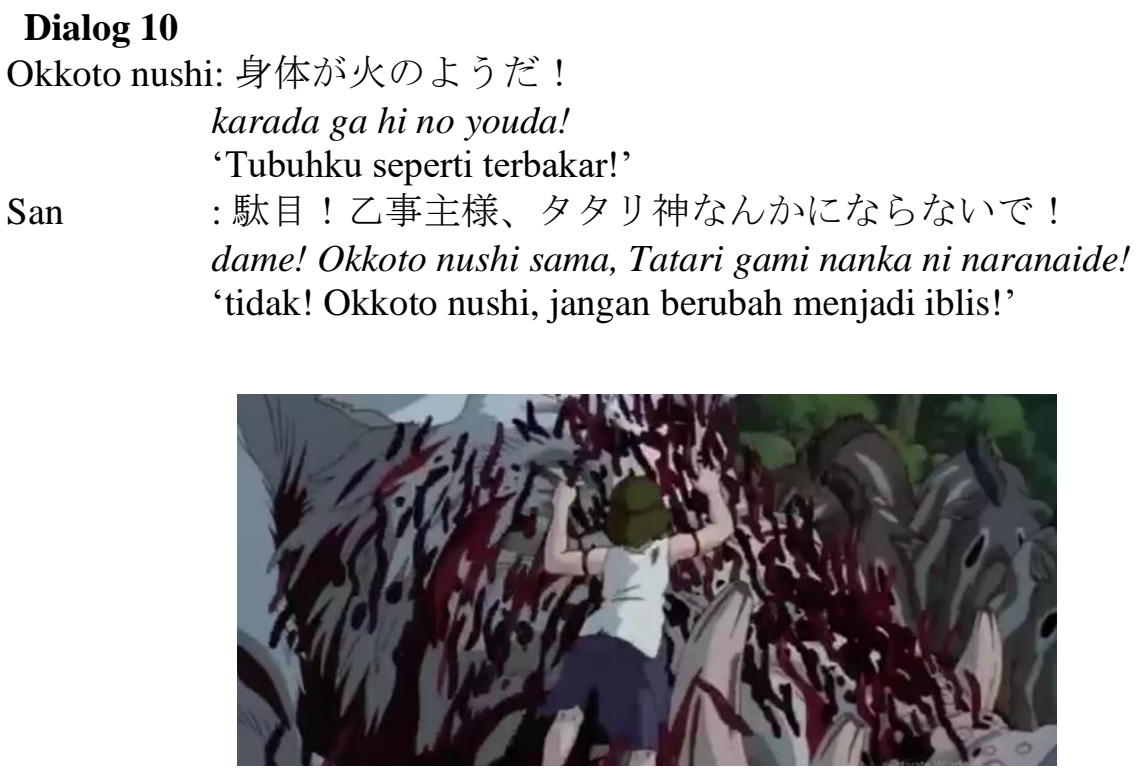

Gambar 3.6 San berusaha menolong Okkoto

Analisis dari percakapan dan gambar diatas adalah keegoisan dapat menimbulkan tragedi dan kesedihan mendalam bagi semua makhluk hidup sehingga munculnya cacing parasit bukan hanya dari kebencian saja, tapi juga kesedihan mendalam pun menjadi faktor pemicu berubah menjadi dewa iblis.

\subsection{Orangutan (猿, 'Saru')}

Berdasarkan legenda Jepang, Shoujyo (猩々)merupakan seekor kera yang memiliki ekor panjang, wajah seperti manusia, cerdas, dan dapat berjalan seperti manusia. Dikatakan Shoujyou mempunyai mata yang merah dan biasanya menghabiskan hidup mereka bermain di laut dan di pasir pantai terpencil sambil meminum alkohol dalam jumlah besar. Mereka menikmati kekonyolan saat mabuk, bernyanyi, menari, dan menikmati hidup. Namun, terlepas dari penampilan dan sikap konyol mereka, mereka dikatakan makhluk yang sangat bijak.

Dalam film ini Shoujyou digambarkan dalam karakter yang dipercayai memiliki kemampuan untuk berkomunikasi kepada manusia. Tidak dijelaskan nama pemimpin atau salah satu karakter dari suku kera ini. Namun jika para Shoujyou murka karena manusia membabat pohon-pohon di hutan, tempat tinggal dan 
sumber makanan para Shoujyou. Para Shoujyou lebih memilih untuk mempertahankan dan melindungi hutan dengan cara menanam pohon yang sudah dibabat dan mati. Masyarakat jepang juga menyakini jika monyet, kera dan sejenisnya, dianggap sebagai hewan yang mempunyai banyak anak dan ahli dalam mendidik anaknya. Maka dari itu tidak heran jika masyarakat jepang menganggap hewan ini sebagai sesuatu yang melambangkan kesuburan dan pendidikan.

Dalam percakapan antara Eboshi dan Ashitaka, alasan Eboshi selalu mengawasi hutan yang sudah gundul adalah karena suku kera setiap hari mencoba menanam benih pohon untuk mengembalikan hutan seperti sedia kala.

\section{Dialog 11}
Eboshi : また来ていたか！夜になるとああして戻ってくるのだ。 山を取り戻そうと木を植えに来る。アシタカ、ここに留

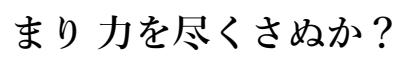
Mata kite ita ka? Yoru ni naruto aashite modotte kuru noda. Yama wo torimodosou to ki wo ue ni ki ru. Ashitaka, koko ni tomari ryoku wo tsukusanu ka?
'Mereka kembali lagi! Ketika malam, mereka akan kembali seperti itu. Mereka datang dan menanam pohon untuk mengambil kembali gunungnya. Ashitaka, mau kah kamu tinggal disini dan mengelola untuk kami?'

Dari percakapan ini dapat terlihat kegiatan para Shoujyou adalah menanam pohon yang telah mati atau dirusak makhluk lain. Berperan untuk melestarikan lingkungan hutan dewa rusa dan merawatnya agar dapat ditinggali oleh semua makhluk hidup.

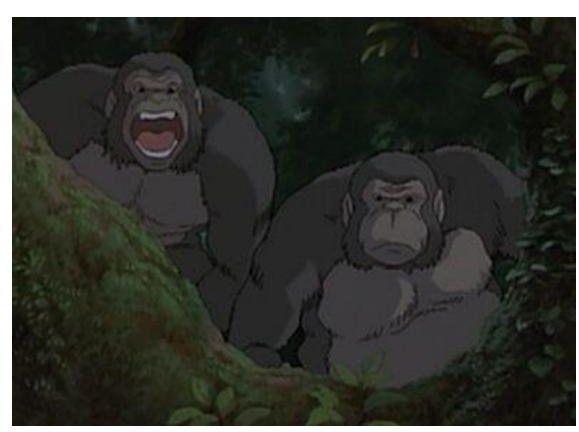

Gambar 4.1 Shoujyou 


\section{Simpulan}

Dari masing-masing karakter memiliki tugas dan peran yang berbeda-beda. Seperti Shishigami yang memimpin para Kami dan makhluk hidup, menjaga segala aktivitas, pemegang hak kehidupan dan kematian, serta disegani dan dihormati oleh semua Kami dan makhluk lainnya. Inugami dan Inoshishigami yang memiliki peran sebagai pelindung dan pengawas hutan dewa rusa. Lalu terakhir adalah Shoujyou yang memiliki peran sebagai makhluk yang melestarikan hutan agar nyaman dan enak ditinggalin oleh makhluk hidup lainnya. Tetapi semua percaya apapun keputusan akhirnya berasal dari Kami terhormat yaitu Shishigami. Kami lainnya tidak ada yang berani untuk membantah keputusan Shishigami karena Shishigami adalah kekuatan dewa tertinggi di hutan ini. Kesimpulan dari penelitian ini akan ditulis dalam tabel yang menunjukkan nama hewan dalam film Mononoke Hime, karakter dan makna. Karakter dari hewan-hewan yang ditunjukkan dalam film ini akan di rumuskan pada tabel karakter hewan. Berikut analisis yang dapat diambil oleh peneliti :

\begin{tabular}{|c|c|c|c|}
\hline No. & Nama Hewan & Karakter dalam film & Makna \\
\hline 1. & Rusa (鹿 'Shika’) & Shishigami & $\begin{array}{l}\text { 1. Pelindung } \\
\text { 2. Persatuan dan kesatuan } \\
\text { 3. Kekuatan } \\
\text { 4. Pembuat keputusan }\end{array}$ \\
\hline 2. & $\begin{array}{l}\text { Serigala } \\
\text { (狼 'Okami’) }\end{array}$ & $\begin{array}{l}\text { Inugami } \\
\text { (Moro) }\end{array}$ & $\begin{array}{ll}\text { 1. } & \text { Kesetiaan } \\
\text { 2. } & \text { Pelindung } \\
\text { 3. } & \text { Kasih sayang } \\
\text { 4. } & \text { Bijaksana } \\
\text { 5. } & \text { Berakal }\end{array}$ \\
\hline 3. & $\begin{array}{l}\text { Babi hutan } \\
(\text { イノシ シ , } \\
\text { 'Inoshishi') }\end{array}$ & $\begin{array}{l}\text { Inoshishigami } \\
\text { (Okkoto nushi) }\end{array}$ & $\begin{array}{l}\text { 1. Bijaksana } \\
\text { 2. Pantang menyerah } \\
\text { 3. Setia kawan } \\
\text { 4. Bekerja sama }\end{array}$ \\
\hline 4. & $\begin{array}{l}\text { Orangutan ( 猿, } \\
\text { 'Saru') }\end{array}$ & Shoujyou & $\begin{array}{l}\text { 1. Cinta lingkungan } \\
\text { 2. Adil }\end{array}$ \\
\hline
\end{tabular}

Berdasarkan analisis data di atas, masing-masing karakter hewan ini memiliki keterkaitan dengan mitos Jepang sebagai berikut :

1. Rusa (Shishigami) : Karakter dari dewa rusa ini juga memiliki persamaan dengan makhluk mitos Jepang yang masih diyakini ada keberadaanya secara turun temurun yaitu Daidarabotchi. Menurut buku Youkai karya Mizuki 
Shigeru, Daidarabotchi berasal dari kota Toyohashi Perfektur Aichi pada zaman Edo. Daidarabotchi ini berwujud raksasa berukuran sebesar gunung dan memiliki langkah kaki kuat sehingga terasa seperti gempa bumi.

2. Serigala (Inugami) : Karakter hewan Moro ini juga memiliki persamaan dengan makhluk mitos yaitu Inugami. Menurut buku Youkai karya Mizuki Shigeru, Inugami memiliki dua jenis yaitu roh anjing yang secara tiba-tiba muncul dan roh anjing yang memang sengaja dipanggil. Inugami dapat pada zaman dahulu disembah seperti dewa karena dapat menyembuhkan penyakit yang tidak bisa disembuhkan oleh tabib. Inugami ini juga dapat melayani manusia layaknya hewan anjing pada umumnya jika kita sering menyembahnya. Kisah Inugami ini sangat populer di wilayah Cina, Shikoku dan Kyuushu.

3. Babi Hutan (Inoshishigami) : karakter hewan Okkoto nushi memiliki persamaan dengan karakter Babi hutan atau Inoshishigami yaitu Katamimi atau Babi bertelinga satu. Namun disini roh katamimi ini tidak memiliki tubuhnya yang lengkap. Jika bertemu dengan makhluk ini biasanya akan terkena kesialan, contohnya dengan cara berjalan melewati celah kaki manusia saat sedang berjalan. Lalu manusia yang dilewati oleh roh ini akan tersedot jiwanya dan mati atau bisa menjadi bodoh. Cara menghindari kesialan dari Katamimi ini adalah dengan menyilangkan kedua kaki. Kisah Katamimi ini sangat terkenal dari Perfektur Kagoshima wilayah Pulau Amami tepatnya disekitar Balai Kota Amashi.

4. Orangutan (Shoujyou) : Makhluk mitologi yang memiliki kesamaan dengan Shoujyou adalah Saru Oni (猿鬼). Namum Saru Oni cukup berbeda dari penggambaran karakter Orangutan di film Mononoke Hime. Saru Oni ini suka membuat onar dengan cara menyerang manusia atau hewan ternak. Akibat dari perbuatan Saru Oni ini, banyak penduduk yang menderita dan akhirnya berdoa kepada dewa pelindung untuk membasmi roh ini. Jadi dikirimkan lah pasukan untuk membasmi Saru Oni yaitu bernama Jenderal Kiri Yoshinau. Tanduk dari Saru Oni ini dismpan di kuil Iyahime dan disimpan dengan cukup baik. 


\section{Daftar Pustaka}

Berger, A.A. 2015. Pengantar Semiotika (Tanda - Tanda Dalam Kebudayaan Kontemporer). Yogyakarta: Tiara Wacana.

Danandjaja, James. 1997. Folklor Jepang: Dilihat Dari Kacamata Indonesia. Jakarta: PT. Pustaka Utama Grafiti

Nur Dianti, Muji. 2018. Analisis Karakter Baik Tokoh - Tokoh Dalam Dongeng Soratobu Toranku Karya H.C. Andersen. Skripsi. Purwokerto: Universitas Jenderal Soedirman.

Widiastuti, Ida Ayu. 2014. Wacana Konflik Lingkungan Dalam Teks Film Animasi Mononoke Hime Karya Hayao Miyazaki. Skripsi. Denpasar: Universitas Udayana.

Barthes, Roland. 2018. Mitologi (Edisi Revisi). Bantul: Kreasi Wacana.

McDonald, Roslyn. 2004. Studio Ghibli Feature Films and Japanese Artistic Tradition. Vol 1 nomor 2, h. 1-9.

Mayumi, Kozo dkk. 2005. The Ecological and Consumption Themes of The Films of Hayao Miyazaki. Science Direct. Ecological Economics 54, h. 1-7.

Alexandra, Putri. 2017. Kajian Mitos terhadap Representasi Karakter Hewan pada Film Animasi Bakemono no Ko. Institut Seni Indonesia Yogyakarta. Desain Komunikasi Visual Vol 1, h. 2-19

Shigeru, Mizuki. 2018. Yokai Picture Book by Mizuki Shigeru. Jepang : Kodansha 